\title{
AS SERVIDÕES REVISITADAS (UM PANORAMA DAS SERVIDÕES NO CÓDIGO DE 2002)
}

\author{
THE REVISITED SERVITUDES (A VIEW OF \\ SERVITUDES IN THE CODE OF 2002)
}

\author{
Roberto Wagner Marquesi"
}

Resumo: Abordagem a respeito das servidões no Código Civil de 2002. Este artigo apresenta um panorama das servidóes na nova ordem privada, enfrentando-as sob a ótica dos princípios que governam o Direito das Coisas e a partir dos conceitos da repersonalização e publicização do Direito Civil.

Palavras-Chave: Servidões, Novo Código Civil.

\begin{abstract}
Approach regarding the servitudes in the Civil Code of 2002. This article presents a view of the servitudes in the new private order, facing them under the optics of the principles that govern the Property law and concept of the personalization and publicization of the Civil law.
\end{abstract}

Key-words: Servitudes, New Civil Code.

\footnotetext{
"Mestre em Direito Civil. Professor dos Cursos de Graduação e Pós-Graduação em Direito da Universidade Estadual de Londrina. Membro do Instituto de Direito Civil (RJ). Autor da obra Direitos Reais Agrários \& Função Social. Curitiba: Juruá, 2001. marquesi@uel.br.
} 


\section{INTRODUÇÃO}

O novo Diploma Civil, vigente a partir de janeiro de 2003, trouxe alterações substanciais no tocante ao Direito das Coisas, das quais se destacam a extinção da enfiteuse, a introdução da superfície e a previsão dos direitos reais de aquisição. Em relação ao instituto das servidões, não se operaram modificações de vulto, exceto uma alteração pontual que não interfere na visão global do instituto.

Sem embargo, as servidões devem ser vistas segundo os princípios informadores da nova ordem civil, especialmente o da função econômica dos direitos reais e o da socialidade, não se as excluindo da idéia da repersonalização do Direito Civil. Revisitadas e vistas a partir dessa angulação, as servidões desbordam de sua finalidade particular e individual para galgarem a condição de instrumento para a consecução dos fins da sociedade.

\section{CONCEITO. FUNÇÃO SOCIAL DAS SERVIDÕES CIVIS}

A raiz etimológica do substantivo servidão é indicativa de sua compreensão atual. No passado, o vocábulo servus designava a pessoa sujeita à discricionariedade e dominação física de outrem. Na Idade Média, viu-se a figura do servo da gleba, que tornava uma pessoa acessória do feudo onde empreendia seu esforço físico. Quer se trate de sujeição a determinada pessoa ou de sujeição à terra, num e noutro caso o vocábulo expressa a idéia de submissão ou subserviência. E é nesse sentido, o de sujeição, que o instituto das servidões deve ser visto e compreendido no sistema jurídico. Evidentemente, na idade contemporânea não há mais falar em submissão de pessoas, senão de coisas, dada a elevação da liberdade individual à condição de direito fundamental. As servidões, no âmbito das coisas, estabelecem-se entre prédios. Prédio, segundo a nomenclatura adotada pelo legislador, designa os imóveis em geral, pouco importando sua estrutura ou localização. Qualquer imóvel é um prédio. Prédio edificado, prédio não edificado, prédio urbano e prédio rústico são denominações encontradiças nas leis em geral e outra coisa não significam além de um bem imóvel. 
Cuidando-se de direitos constituídos sobre coisa alheia, necessariamente um prédio alheio, as servidões restringem o uso desse imóvel. Em outras eras falava-se de servidões prediais e de servidões pessoais. As primeiras eram as que se estabeleciam para o incremento de um imóvel determinado; as segundas as que se firmavam em favor de uma pessoa determinada. Nestas se enquadravam o usufruto, o uso e a habitação; naquelas, as servidões propriamente ditas. Hoje, usufruto, uso e habitação não mais são vistos como servidões, sem embargo de seguirem como direitos reais limitados. As servidões de hoje só se perfazem entre prédios, estabelecendo restrições em um para serventia de outro. Logo, tornou-se pleonástica a fórmula "servidões prediais", no que andou bem o Código de 2002 ao estabelecer a expressão "servidões" apenas, tal como se vê dos arts. 1378 e ss.

Instituto dos mais antigos, as servidões partem da constatação de que o uso e a fruição dos imóveis nem sempre podem propiciar ao titular as vantagens que este almeja. Determinado fundo rural, que explora laranjais, não dispõe de água bastante para suas necessidades; outro, que faz colheita periódica de grãos, apresenta problemas para escoá-los; um imóvel urbano edificado, localizado na orla marítima, permite bela paisagem do oceano, mas a construção de um muro, pelo vizinho, pode eliminar essa comodidade. Nestes exemplos, os proprietários poderão suprir as carências ou manter a comodidade de seus respectivos prédios valendo-se dos imóveis vizinhos. Destarte, no primeiro exemplo, o dono dos laranjais obtém autorização para captar água do imóvel vizinho; no segundo, o proprietário consegue o direito de passagem no fundo contíguo para melhorar o escoamento da safra e, no último, o dono do prédio urbano obtém a obrigação do vizinho de não erguer muro acima de determinada altura. Tais utilidades, obtidas em favor de um prédio à custa do sacrifício de outro, são servidões.

As servidões podem ser conceituadas como restrições suportadas por um prédio para utilidade de outro, pertencente a dono diverso. $\mathrm{O}$ imóvel que as suporta é o "prédio serviente", assim chamado por achar-se sujeito ao uso e gozo exercidos pelo dono do imóvel alheio. O imóvel em cujo proveito elas se fazem é o "prédio dominante", que recebe essa denominação por sujeitar o outro às restrições. Tal conceituação transparece da primeira parte do art. 1378 do Código: 
"a servidão proporciona utilidade para o prédio dominante, e grava o prédio serviente, que pertence a diverso dono [...]".

Uma vez constituídas, as servidões geram direitos reais, oponíveis contra todos e acompanhando o imóvel gravado. A alienação do prédio serviente não as extingue, portanto. Quem quer que o adquira, deverá suportar o gravame.

Não há divergência doutrinária em torno do conceito de servidão. A manualística a vislumbra com um direito real sobre coisa alheia, exercido por proprietário ou possuidor de um imóvel, porém sempre vinculando dois ou mais prédios. Cabal a conceituação apresentada Spencer Vampré (1920, página), para quem as servidões são:

um direito real, voluntariamente imposto a um prédio em favor de outro, e em virtude do qual perde o proprietário do primeiro o exercício de algum direito dominial, ou é obrigado a tolerar que dele se utilize o proprietário do segundo, tornando este último mais útil ou, pelo menos, mais agradável.

Da conceituação extrai-se a finalidade das servidões. Seu objetivo é o de tornar mais útil, cômodo ou agradável o prédio dominante. A finalidade lucrativa não é requisito basilar, embora seja a causa mais freqüente de sua constituição. Basta o gravame propiciar uma vantagem ao prédio dominante, qualquer que seja ela, para justificar sua instituição. Nos exemplos acima citados, não se vislumbra nenhum propósito lucrativo na não construção do muro divisório. Ali interessa apenas o deleite do proprietário e dos possuidores do prédio dominante.

Assentado que as servidões destinam-se a suprir as carências de determinado imóvel, ainda que com restrições a outro, nelas se pode entrever uma vocação social. Para San Tiago Dantas (1984, p. 316), cuida-se de "um meio de que se serve o direito para corrigir a desigualdade natural entre os prédios". Se a natureza os fez desiguais, de forma que um seja mais aquinhoado do que o outro, estabelece-se um desequilíbrio natural e a necessidade de atenuá-lo, para que cada um dos prédios possa, na medida do possível, atingir sua potencialidade. A busca desse equilíbrio e o equacionamento dos interesses entre os proprietários permitem qualificar as servidões como portadoras de uma função social. Que elas se façam quase sempre por contrato, gratuito ou oneroso, é de somenos importância e não infirma essa conclusão. 
Nessa linha de raciocínio, Ricardo Aronne (2001, p. 330) assevera que as servidões são "um instituto que traz uma órbita de funcionalização ao prédio serviente, ao possibilitar que o prédio dominante melhor atenda a função social, ampliando seu domínio com parcela dominial do prédio serviente". Disso se extraem duas conclusões importantes: primeiro, a afirmação, amplamente divulgada e aceita pela doutrina e pelos tribunais, de que as servidões são uma relação entre prédios, deve ser vista com cautela, na medida em que são feitas por pessoas e para acudir a interesses delas (lembre-se aqui da obrigacionalização dos direitos reais); segundo, a existência das servidões atende ao princípio cardeal da socialidade, um dos pilares da codificação de 2002 e que prevê um ideal de cooperação entre os atores sociais, vale dizer entre os proprietários.

Tais asserções, dotadas de alta carga valorativa, servem de guia na análise do instituto, que, porquanto jungido à órbita das titularidades privadas, deve ser estudado sob a ótica da funcionalização.

\section{ESCORÇO HISTÓRICO}

As servidões existem desde priscas eras, apresentando-se como um dos mais antigas formas de constituição de poder sobre coisas e um dos fenômenos jurídicos que menos alterações sofreram na história. A Lei das XII Tábuas ${ }^{1}$ (450 a.C.) já as contemplava, embora limitandose aos prédios rústicos. Dentre outras disposições, a Tábua VII continha regras sobre as servidões de passagem e de aqueduto, além de garantir indenização pelos danos causados pelo dono do prédio dominante. As servidões urbanas só apareceriam por volta de 490 a.C., quando da destruição de Roma pelos gauleses. Destacam-se as servidões de vista, de esgoto e de passagem. Uma das características da servidão romana dos primeiros tempos é a tipicidade, o que vale dizer não ser lícita a constituição de servidões não previstas em lei.

A codificação justinianéia (528-534 d.C.) não altera substancialmente o panorama geral, protegendo as servidões rústicas e prediais. Mas já admite a constituição de servidões atípicas, segundo a conveniência das partes. A essa época já se conheciam, além das

\footnotetext{
${ }^{1}$ Assim chamada porque redigida em doze lâminas de bronze.
} 
modalidades mencionadas, as servidões de tapagem, de deitar goteiras no prédio vizinho, de extrair areia, de não edificar, de travejar etc. Todas essas formas perduram até os dias de hoje, embora algumas delas tenham sido deslocadas para o regime de vizinhança, formando o que alguns impropriamente denominam "servidões legais".

A Idade Média assiste ao atrofiamento das servidões, na esteira da politização do direito de propriedade, que perde sua significação econômica para tornar-se expressão de poder político. $\mathrm{Na}$ verdade, as servidões sempre estiverem umbilicadas à propriedade e variaram segundo se alterava a concepção político-econômica do domínio. Natural, portanto, que seu regime tenha acompanhado a idiossincrasia medieval sobre propriedade. Ainda assim, fala-se em servidão pessoal, no sentido de submissão do camponês à gleba feudal. Não se cuida, evidentemente, de servidões entre bens.

Razões ideológicas estarão presentes também no Código de 1804. Temendo um retrocesso ao medievo e buscando apagar qualquer traço de submissão, quer entre pessoas e coisas quer entre bens, seu art. 638 timbra a regra de que a servidão não cria qualquer ascendência de um prédio sobre outro (RUGGIERO, 1999). Claro que essa asserção não visava impedir a constituição ou mesmo a disseminação das servidões; ao revés, foi concebida apenas para realçar o absolutismo do direito de propriedade, bem ao sabor da burguesia emergente. As servidões napoleônicas não se inspiram no modelo de propriedade funcionalizada.

Com a ideologia humanista dos direitos reais, divulgada na Europa em meados daquela centúria, as servidões assumem o perfil que hoje ostentam, vale dizer, um direito real constituído por proprietários diversos, para favorecimento de um prédio em detrimento de outro, destinado à funcionalização daquele, segundo a idéia da socialidade.

\section{DELIMITAÇÃO DAS SERVIDÕES CIVIS}

As servidões previstas no Código Civil, outrora chamadas "servidões prediais", não podem ser confundidas com as restrições oriundas dos direitos de vizinhança (CC, arts. 1277 a 1313) nem com as servidões de ordem administrativa, ainda que com ambas guarde grande similitude. Tal como nas restrições de vizinhança, as servidões impõem 
obrigações negativas ao proprietário, delimitando o uso do imóvel, mas ambas são inconfundíveis, e por duas razões: a uma, porque as restrições da vizinhança derivam da lei, enquanto as servidões decorrem quase sempre de um acordo de vontades; a outra, porque, enquanto as segundas satisfazem a um interesse particular, as segundas destinamse ao resguardo do trinômio sossego/saúde/segurança, como forma de assegurar a convivência pacífica entre os vizinhos.

Exemplo palpitante está no art. 1285, que trata do prédio encravado: o dono de imóvel sem acesso a via pública pode "constranger" o vizinho a lhe dar passagem. O vocábulo em destaque é expressivo, pois as servidões não podem ser impostas e, na generalidade dos casos, só se constituem por ato de vontade do dono do imóvel serviente. Logo, a figura desse dispositivo não se afeiçoa a uma servidão; é restrição decorrente da vizinhança e, como tal, prevista no Código. Mesmo assim, há quem diga tratar-se de "servidão legal".

As servidões civis também não podem ser confundidas com as servidões administrativas. Ambas têm em comum o fato de restringirem os poderes do proprietário, delimitando-lhe o uso e gozo do prédio através da criação de uma obrigação negativa. Todavia, enquanto as segundas decorrem de ato do poder público, as primeiras têm origem particular. Naquelas, o Estado restringe o uso do imóvel para o atingimento de uma dada finalidade pública, como, por exemplo, a passagem de cabos de alta tensão ou de aquedutos de empresa pública de saneamento (Lei 3365/41). Outros exemplos encontram-se nos oleodutos e gasodutos. Venosa (2003, p. 403) cita como exemplo de servidão administrativa a obrigação de não edificar acima de certa altura na região dos aeroportos. Além disso, as servidões administrativas podem ser impostas ou por sentença ou por acordo entre o poder público e o particular. Finalmente, há de ressaltar que, nessa espécie de servidão, não se fala em prédio dominante, uma vez que ela é instituída não para incrementar a utilidade de um imóvel, mas para assegurar um interesse público.

\section{CARACTERÍSTICAS DAS SERVIDÕES}

Várias são as características a diferenciar as servidões dos demais direitos reais limitados. Conhecê-las é de fundamental importância 
para apreender-lhes a morfologia e a finalidade. Tais caracteres são milenares e já haviam se firmado no direito romano.

A) Diversidade de prédios e de proprietários. As servidões são constituídas para aumentar a utilidade de um prédio (prédio dominante) à custa da diminuição da utilidade de outro (prédio serviente). Se o prédio é bastante para propiciar a utilidade almejada pelo proprietário, não precisará este socorrer-se de outro imóvel. Assim, não constituem servidão os chamados corredores de passagem, que o proprietário implanta em seu imóvel para que o gado percorra determinado caminho até a fonte de água. Trata-se de simples "serventia", decorrente do exercício racional do domínio. Pela mesma razão constituem serventias, e não servidões, as vinculações que se fazem entre dois prédios, para benefício de um e restrição do outro, pertencentes ao mesmo titular. Trata-se, também, de exercício racional dos poderes dominiais, dimensionados para funcionalizar o imóvel e melhor atender aos interesses do titular. Logo, se o dono do imóvel $\mathbf{A}$, que tem acesso ao rio, instala um aqueduto para favorecer o prédio $\mathbf{B}$, que está mais afastado da água mas também lhe pertence, não há cogitar na figura de uma servidão, que aqui se mostraria inócua e sem sentido.

Não se exige, ademais, a contigüidade entre os prédios. Basta sejam vizinhos, mas próximos o bastante para permitir a constituição do gravame e a utilidade. Exemplo clássico é o da servidão de aqueduto, na qual a água é captada no prédio serviente, percorrendo vários outros até ser despejada no prédio dominante.

É importante salientar, nessa linha de raciocínio, que as servidões são uma relação objetiva entre prédios. Não se trata, à evidência, de uma relação jurídica entre coisas, eis que somente o homem pode ser titular de direitos e obrigações. O que existe é uma vinculação de ordem objetiva, que se expressa no mundo fenomênico, a enlaçar e afetar imóveis distintos. $\mathrm{O}$ ato concretizador dessa vinculação decorre, geralmente, da vontade dos proprietários. Por isso diziam os romanos que a servidão serve à coisa, não a pessoas.

B) Acessoriedade. As servidões não têm existência autônoma; são direitos reais acessórios, eis que sua existência depende da existência do prédio dominante, ao qual se vinculam. Disso decorrem conseqüências importantes. Assim, a alienação, a desapropriação, 
a hipoteca, em suma todos os atos de disposição praticados pelo dono do prédio dominante, afetarão as servidões, que seguirão a sorte do prédio, acompanhando-o e abstraindo a figura do proprietário. Manifesta-se aqui o direito de seqüela. Penhorado para garantir uma execução o prédio dominante, a garantia abrangerá a servidão. As servidões deambulam com o prédio dominante. Por isso que não podem ser penhoradas, hipotecadas ou alienadas isoladamente.

C) Geram obrigação de não fazer. Um dos traços marcantes das servidões repousa na natureza da obrigação que elas geram, a implicar uma conduta de abstenção ou tolerância, vale dizer uma obrigação negativa a ser observada pelo proprietário e possuidores do prédio serviente. Se alguém convenciona não erguer muro acima de certa altura para preservar a boa visão do prédio vizinho, assumirá obrigação de abster-se. Se um proprietário aceita a passagem de pessoas em seu imóvel, acordando uma servidão de trânsito, será dever seu tolerar a passagem. Ambas são obrigações de conteúdo negativo.

E é nesse sentido que se há de transcrever o art. 1383: o "dono do prédio serviente não poderá embaraçar de modo algum o exercício legítimo da servidão". A inércia é uma idéia que deve acompanhar o titular do prédio serviente.

As obrigações de dar ou fazer não se afeiçoam ao espírito das servidões. O prédio serviente experimenta uma diminuição de sua utilidade, fazendo-o em favor de outro prédio. Não seria razoável exigir um sacrifício maior do proprietário, impondo-lhe condutas positivas. Por essa razão, referindo-se à conservação das servidões, dispõe o art. 1381 que as obras respectivas "devem ser feitas pelo dono do prédio dominante, se o contrário não dispuser expressamente o título".

D Indivisibilidade. Indivisíveis são as coisas que não se podem partir sem dano a sua substância ou os direitos e deveres que, exercidos por um só dos vários titulares, a todos aproveitam. As servidões não podem ser fracionadas, porque isso repercutiria negativamente no prédio dominante. De tal assertiva extraem-se algumas conseqüências. Assim, a divisão do prédio dominante ou do serviente, seja para fins de desconstituição de condomínio seja por 
efeito de herança, em nada interferirá no gravame. A morte do titular do prédio dominante e a investidura de vários herdeiros na sua propriedade permitirão que cada um deles exerça a servidão. Da mesma forma, se os vários condôminos do prédio dominante resolverem desconstituir o condomínio, dividindo o imóvel e gerando várias propriedades distintas, cada uma delas aproveitará a servidão. Doutro lado, partilhado o prédio serviente e constituído um condomínio ordinário, cada um dos novos titulares deverá suportar o gravame como um todo.

Igual raciocínio aplica-se aos casos de ação movida por um só dos condôminos para resguardar a servidão. A sentença a todos aproveitará. De igual forma, o exercício da servidão, por um só dos condôminos, basta para mantê-la e, ainda que os demais a não exerçam, ela se conservará para todos.

Nesse sentido o art. 1386 do Código, segundo o qual:

as servidões prediais são indivisíveis, e subsistem, no caso de divisão dos imóveis, em benefício de cada uma das porções do prédio dominante, e continuam a gravar cada uma das do prédio serviente, salvo se, por natureza, ou destino, só se aplicarem a certa parte de um e de outro.

Exemplo da ressalva contida na parte final deste dispositivo ocorre nas servidões de extrair areia. Supondo que ela se encontre numa porção específica do imóvel serviente, dividido este, suportará a servidão apenas o proprietário a quem couber aquela porção.

Mas, se as servidões são indivisíveis, não o é seu exercício. Logo, os condôminos do prédio dominante podem regulamentar o trânsito na servidão segundo critérios cronológicos, estabelecendo os horários ou os dias em que cada um poderá exercitá-la. O condômino A, v.g., transita com suas reses em determinados períodos da manhã e da tarde, reservando-se ao condômino $\mathbf{B}$ o trânsito de caminhão nos demais horários e à noite;

E) Atipicidade. Como se viu na análise histórica do instituto, em eras remotas só se podiam criar servidões cujo tipo estivesse previsto em lei. Assim foi na Lei das XII Tábuas (450 a.C.), mas assim já não era no Digesto (534 d.C.). Hoje, conhecem-se várias espécies de servidão. Há muito o sistema abandonou a idéia de tipificar as servidões e enclausurar sua criação. Agora, deixa-as à conveniência das partes, partindo da noção de que, em havendo necessidade de 
um prédio e concordância do dono do imóvel vizinho, poderá realizar-se a restrição. É certo, porém, não ser lícito às partes constituir servidões ofensivas à ordem pública;

F) Tendência à perpetuidade. Diz-se serem perpétuas as servidões. Isso não quer dizer sejam eternas, mas sim que têm duração geralmente indeterminada, prevalecendo enquanto permanecerem as necessidades do prédio dominante. $\mathrm{Na}$ generalidade dos casos, as servidões são constituídas sem determinação de prazo e são criadas com esse ânimo, mas nada impede tenham um termo final prefixo. Pode-se dizer terem elas uma tendência à perpetuidade, pois é razoável supor que a carência do imóvel dominante tenha um caráter permanente. Uma vez que são direitos reais e aderem ao imóvel, acompanham-no indefinidamente ou até o advento de uma causa de extinção (arts. 1387 e ss.);

G) Voluntariedade. Várias são as formas constitutivas de servidão e delas se falará adiante. Mas, dentre elas predomina o negócio jurídico, ou seja, a manifestação de vontade dos proprietários no sentido de criá-la. E é justamente na voluntariedade que as servidões civis se distinguem das servidões administrativas e dos direitos de vizinhança, como visto linhas atrás. As demais formas de constituição de servidão (usucapião, sentença, destinação do proprietário) são excepcionalíssimas, não sendo exagero falar na voluntariedade como uma característica inerente ao instituto;

H) Impresumibilidade. Porque direitos reais imobiliários, as servidões sempre são formais e solenes, dando-se por escrito e mediante averbação à margem da matrícula do imóvel. Enquanto não se operar o registro, haverá mera relação pessoal entre as partes. Por isso não podem ser presumidas, hão de estar expressas. Várias são as conseqüências de sua não presumibilidade, das quais se destaca, v.g., a interpretação restritiva. Sempre que surdirem dúvidas sobre a existência ou amplitude das servidões, deverá o juiz decidir em favor do dono do prédio serviente, já que seu titular suporta o encargo.

No caso de uma servidão de trânsito, por exemplo, havendo dúvidas sobre se ela permite apenas a passagem de pedestres ou também de veículos, não se podendo concluir pela verdadeira intenção das partes, decidirá o juiz pela primeira solução, em prestigiamento à exegese restritiva. A situação guarda simetria com a regra do art. 114 do Código, 
graças ao qual "os negócios jurídicos benéficos e a renúncia interpretamse estritamente". Como a servidão é avençada em proveito de um com o sacrifício de outro, razoável que assim se a deva interpretar.

\section{CLASSIFICAÇÃO}

As servidões podem ser classificadas segundo dois critérios. Levando em conta sua apresentação no prédio serviente, podem ser "aparentes" ou "não aparentes". Tendo em mente a forma de seu exercício, podem ser "contínuas" ou "descontínuas". Classificá-las à luz desses critérios é tarefa de suma importância, na medida em que sua constituição, proteção, exercício e extinção recebem diferente tratamento conforme a espécie onde se enquadram. Outro critério poderia ser mencionado, como o da localização, que biparte as servidões entre urbanas e rústicas, segundo se perfaçam em prédio urbano ou rural. Todavia, esta classificação é de nenhuma importância prática e teórica e pode ser demitida deste estudo.

Aparentes são as servidões perceptíveis ao exame ocular no prédio serviente, porquanto possuem existência concreta, fenomênica, apreensível aos sentidos. Tais servidões se percebem por obras no solo, subsolo ou espaço aéreo, instalação de materiais ou benfeitorias, como cercas, pontes, tubulações, cabos aéreos etc. Ser aparente não significa que a servidão deva ser percebida à simples corrida de olhos. A servidão de aqueduto, por exemplo, está instalada no subsolo e, ainda assim, é aparente. O que de fato importa é estar materializada a servidão.

Não aparentes são as servidões sem existência física. Não possuindo existência concreta, são insuscetíveis de apreensão pelos sentidos, razão por que não podem ser detectadas por inspeção ocular nos prédios. Sua existência só se apurará mediante consulta à matrícula imobiliária. Exemplo clássico dessas servidões é a de não edificar muro acima de certa altura (servidão de vista). Inclui-se, ainda, a servidão de não obstruir passagem de luz ou de ar. Ao contrário das aparentes, essa espécie de servidão não se materializa.

Contínuas são as servidões que, uma vez constituídas, não exigem a presença humana para se manter. Sua função econômica é desempenhada sem a intervenção periódica do homem, que, quando muito, diligenciará por sua conservação. Um bom exemplo repousa 
na servidão de aqueduto. Instalados os canos, a água fluirá natural e permanentemente, dispensando ato humano. Idem em relação à passagem de cabos de eletricidade. A servidão de não edificar muro acima de certa altura é também contínua, embora não aparente.

Descontínuas são as servidões que, para se manterem, demandam a presença intermitente do homem, que, a espaços, deverá manifestar seu exercício. É o que acontece na servidão de trânsito de pedestres. Se ela não for exercida, ou seja, se o titular não usar o caminho, o gravame se esvai a ponto de caracterizar o abandono e gerar a extinção. Idem em relação à servidão de extrair areia, a exigir a presença física do proprietário dominante, ainda que intermitentemente.

A importância prática dessa esquematização reside no fato de que somente as servidões contínuas e aparentes podem ser objeto de posse, entendida esta como o exercício de fato dos poderes peculiares ao domínio. Assim é que somente as servidões aparentes podem ser objeto de tutela possessória e somente as aparentes e contínuas podem ser adquiridas pela usucapião. As demais, não. Outra não é a conclusão do disposto nos arts. 1213 e 1379 do Código. Logo, se alguém instala aquedutos em imóvel alheio para levar água até o seu (fenômeno contínuo e aparente), poderá, presentes os requisitos legais (tempo, posse, inércia etc), registrar a servidão em seu nome. As servidões não aparentes são imunes à proteção possessória e à usucapião por uma singela razão: sobre elas não é possível exercer posse. Ninguém pode possuir uma abstração, como seja a servidão de não construir. Em relação às servidões descontínuas também não é possível falar em posse tendente à usucapião, dado seu caráter intermitente, ocasional, episódico, a afastar o animus domini.

Ademais, a extinção pelo não uso (art. 1389, III) só se aplica às servidões descontínuas, pois as contínuas, como se viu, prescindem da presença do titular.

Questão a suscitar algum estudo é a da servidão de passagem. Em princípio, trata-se de servidão não aparente e descontínua, pois nela é difícil saber se existe posse de quem a usa ou mera tolerância do dono do prédio. Todavia, a jurisprudência assentou o entendimento de que a servidão de passagem, desde que detectável por obras, sinais ou vestígios, considera-se aparente, gozando, pois, da tutela possessória. Alguém abre um caminho em imóvel vizinho alheio, isolando-o, 
conservando-o e nele transitando a pé ou com veículos, este é um exemplo de servidão aparente. É a orientação da Súmula 415 do STF: "servidão de trânsito não titulada, mas tornada permanente, sobretudo pela natureza das obras realizadas, considera-se aparente, conferindo direito à proteção possessória”. Sem embargo, porquanto descontínua, tal servidão não pode ser usucapida, diante da vedação do referido art. 1379, a exigir exercício contínuo do direito.

Finalmente, é de aclarar que o fato de uma servidão enquadrar-se num dado critério de classificação não significa, necessariamente, seja excluída de outro. Vale dizer, as servidões podem mesclar-se, gerando as seguintes combinações e conseqüências jurídicas.

a) aparentes e contínuas (são tuteladas pelos interditos, podem ser usucapidas e não se extinguem pelo não uso. Ex: aqueduto e cabos de eletricidade);

b) aparentes e descontínuas (são tuteladas pelos interditos, não podem ser usucapidas e extinguem-se pelo não uso. Ex: via trânsito de veículos delimitada e conservada);

c) não aparentes e contínuas (não são tuteladas pelos interditos, não podem ser usucapidas nem se extinguem pelo não uso. Ex: não edificar muro acima de certa altura);

d) não aparentes e descontínuas (não são tuteladas pelos interditos, não podem ser usucapidas e extinguem-se pelo não uso. Ex: extração de areia ou via de trânsito não demarcada).

A propósito, não me parece correta a asserção, aceita por boa parte da doutrina, de que a proteção possessória só pode ser estendida às servidões aparentes contínuas. Se as servidões são aparentes, nelas existe posse, pois o titular está manifestando seu propósito de utilizá-las. Isso basta para conferir-lhe resguardo interdital, que é um dos efeitos da posse. Se a aparência é acompanhada da continuidade, então se poderá falar em condutibilidade à usucapião, que é um outro efeito da posse.

Dito em outras palavras, significa isso afirmar que todas as servidões aparentes são tuteladas pelos interditos, mas somente as aparentes contínuas podem levar à usucapião. Vale dizer, pois, que ambas implicam posse, embora cada uma gere um efeito diferente.

O sistema jurídico atual não veda a proteção possessória às servidões aparentes, ainda que descontínuas, embora refute sua usucapibilidade. 
É o que se extrai de uma interpretação sistemática dos arts. 1204, 1213 e 1379 do Código. O Projeto 6960/2002, que introduz parágrafos ao art. 1378, nada diz sobre proteção possessória de servidões aparentes, o que significa que não a veda.

Creio que a figura da servidão de trânsito delimitada por sinais, servidão aparente descontínua, é exemplo bastante. Na verdade, como logo abaixo se verá, há uma tendência dos tribunais a considerar tais servidões como contínuas, sujeitas inclusive à usucapião.

\section{FORMAS DE CONSTITUIÇÃO}

Cuidando-se de direitos reais imobiliários, as servidões só adquirem existência com o registro imobiliário, conforme deflui do disposto no art. 1227 do Código. Enquanto não se verificar o registro, haverá mero direito obrigacional. Quando se fala em formas de constituição da servidão, não se quer aludir propriamente a sua constituição, porque esta só o registro tem o condão de operar. $\mathrm{Na}$ verdade, a questão que se propõe neste momento é a de saber quais os títulos aptos a gerarem o registro da servidão. A doutrina apresenta cinco formas aptas a levarem ao registro, quais sejam: a) convenção; b) testamento; c) destinação do proprietário; d) usucapião e e) sentença. Dessas, somente as três primeiras são voluntárias.

A convenção ou contrato é a mais fecunda das fontes criadoras da servidão. Negócio jurídico que se expressa por uma proposta aceita, há de ser feita por escritura pública, valendo entre as partes enquanto não conduzida a registro. $\mathrm{O}$ contrato de servidão pode ser gratuito ou oneroso. Neste caso, o proprietário dominante pagará uma remuneração ao proprietário serviente; naquele, nada será devido. A forma de remuneração fica à discrição das partes, nada dispondo a lei a propósito.

Só os proprietários podem avençar a servidão, pois só a eles assiste o direito de disposição. Não o poderá fazer, contudo, o nu-proprietário, a menos que obtenha anuência do usufrutuário, que é quem tem o uso e gozo da coisa. Também não pode constituir servidão o condômino à revelia dos demais comunheiros, pois, se o fizer, estará a comprometer interesses alheios. Arnaldo Rizzardo (1984) ensina que o proprietário de imóvel dado em hipoteca não pode sujeitá-lo a 
servidão se o gravame diminuir substancialmente a garantia. Correta a opinião, em vista do disposto no art. 333, III, do Código.

Algumas situações exigem maior raciocínio. Por exemplo, aquele que adquiriu o imóvel com cláusula de retrovenda (CC, art. 505), poderá torná-lo prédio serviente? Responde-se afirmativamente, todavia a existência do gravame permanecerá sob condição resolutiva. Caso o vendedor queira recomprar o prédio, a servidão será extinta (CC, art. 1359).

Os possuidores não podem contratar servidão. Assim locatário, usufrutuário, arrendatário, parceiro-agricultor etc.

Também por testamento se pode instituir servidão. É espécie pouco usual, porque o próprio ato de testar não é comum entre nós. O testador deve, necessariamente, ser dono do prédio onde deseja instituir o gravame. À evidência, não poderá constituir servidão onerando terreno alheio. Considerando que o testamento constitui ato unilateral, a servidão dependerá da aceitação do legatário, dono do prédio dominante, para ser constituída.

A convenção e o testamento, como títulos capazes de gerar o registro e o nascimento da servidão, estão previstos no art. 1378 do Código.

A última forma voluntária é a chamada servidão por destinação do proprietário. Tal modalidade não está prevista no sistema, mas o Projeto 6960/2002 sugere sua admissão, na esteira de outros sistemas ocidentais, que a admitem expressamente. Essa forma de servidão nasce do ato de vontade do proprietário que, sendo titular de dois prédios vizinhos, estabelece serventia entre eles, ou seja, uma utilidade ou comodidade de fato. Como a servidão pressupõe dualidade de proprietários, tal serventia não constitui o gravame. Mas poderá vir a sê-lo se o proprietário, seja por que forma for, se desfizer da propriedade de um dos prédios. Isso ocorrendo, a serventia transforma-se em servidão. Vale dizer, portanto, que a destinação, por si só, não faz nascer a servidão e talvez por esse motivo não tenha sido contemplada pelo codificador. Advirta-se que, como toda forma de constituição de servidão, essa modalidade deverá ser registrada.

Vistas as formas voluntárias capazes de gerar um título para a servidão, vejam-se agora as demais modalidades.

As servidões também podem ser adquiridas por usucapião. Tal possibilidade pode causar certa perplexidade ao aluno de direito, 
condicionado a imaginar a usucapião como forma de adquirir propriedade apenas. A servidão é um direito real de uso e fruição e, como tal, é suscetível à usucapião. O usucapiente, titular do prédio dominante, não adquire propriedade; adquire apenas a faculdade de usar e gozar determinado espaço físico do prédio serviente, cujo domínio se mantém com o respectivo titular, ainda que restringido pelo gravame. Não se fala em "dono", senão em "titular" da servidão.

A aquisição da servidão por essa forma reclama os mesmos requisitos da usucapião em geral, ou seja, posse do usucapiente, decurso de tempo, inércia do proprietário, coisa hábil imóvel e sentença. Como visto acima, só as servidões contínuas e aparentes podem ser usucapidas, pois apenas nelas é possível o exercício da posse. O art. 1379, que trata do assunto, não exige expressamente a boa-fé, mas remete ao art. 1242, onde tal figura está presente. Logo, a boa-fé do possuidor é requisito indispensável para usucapir servidões. O que não é necessário é o título. Sua ausência não obsta a usucapião, que, em caso tal, se consumará ao cabo de 20 anos (usucapião extraordinária). Se ele estiver presente, tanto melhor, porque o prazo se reduzirá para 10 anos (usucapião ordinária).

É o que dispõe o art. 1379 do Código: "o exercício incontestado e contínuo de uma servidão aparente, por dez anos, nos termos do art. 1.242, autoriza o interessado a registrá-la em seu nome no Registro de Imóveis, valendo-lhe como título a sentença que julgar consumado a usucapião”.

Ajunta o parágrafo único que, "se o possuidor não tiver título, o prazo da usucapião será de vinte anos".

Para que o usucapiente obtenha a sentença declaratória da usucapião, deverá mover a ação correspondente, geralmente de tramitação demorada, custosa e complexa, como se percebe dos arts. 941 e ss. do CPC. Como explicitado no art. 1379, a sentença, apenas declarando, não tem carga constitutiva. Tal efeito só será alcançado com seu registro no ofício imobiliário.

Como se percebe da leitura do art. 1379, somente as servidões aparentes contínuas podem ser usucapidas. A servidão de trânsito, devidamente conservada por obras e delimitada por sinais, é exemplo de servidão aparente, conforme exposto no item 6 , alínea $b$, exemplo que é também trazido por Venosa (2003). Não poderia ser adquirida por usucapião, portanto. Sem embargo, há decisões a considerar esse tipo de servidão como contínua, dada a presença do espaço físico 
delimitado e das obras promovidas pelo homem para o fito de criá-la e mantê-la (pontes, cercas, empedramento etc.). Passariam a ser, assim, usucapíveis, à semelhança da servidão de aqueduto. Dito em outros termos, a presença de tais obras e acabamentos revelariam o exercício de posse tendente à usucapião.

As servidões podem, finalmente, ser constituídas por sentença. Isso é possível nas ações de divisão de condomínio ordinário (imóveis rurais v.g.), nas quais o juiz, ao dividir o imóvel em vários quinhões, procura compensar a porção menos favorecida valendo-se do gravame. Se uma fazenda é dividida em quatro quinhões, aquele que se encontrar mais distante da via pública (não necessariamente sem acesso a ela) poderá ser contemplado com uma servidão de trânsito para diminuir a distância, compensando a desvantagem natural no escoamento da produção. A sentença que assim dispuser deverá ser registrada para gerar oponibilidade erga omnes. A possibilidade de constituir servidão por essa forma encontra-se no art. 979, II, do CPC.

\section{EXERCÍCIO DAS SERVIDÕES}

O exercício de uma servidão compreende, basicamente, o exercício da posse. Tal permite concluir que se devam analisar os direitos e deveres dos proprietários e possuidores dos prédios dominante e serviente. Conquanto o instituto em apreço pertença ao mundo das coisas, não está imune à incidência de faculdades e deveres intersubjetivos, segundo a idéia da obrigacionalização dos direitos reais. Os arts. 1380 e ss. do Código, arrolados no capítulo "exercício das servidões", tratam especialmente da conduta das partes diante da servidão.

A primeira idéia a ser fixada é a de que as servidões devem ser exercidas moderada e comedidamente, evitando o abuso de direito. Vale dizer, pois, que devem ser exercidas civiliter. O gravame é estabelecido para aumentar a utilidade de um prédio. Mas, para que isso ocorra, impõem-se sacrifícios a outro prédio, cujo uso é restringido. Disso decorre devam ser dosados tanto a necessidade do dominante quanto o sacrifício do serviente, de forma a atingir um equilíbrio. Este é alcançado quando o dominante atinge o máximo de utilidade com o mínimo de sacrifício do serviente. Se um imóvel ressente-se de água, pode captá-la no outro, desde que, ao fazê-lo, não vá além de sua 
necessidade nem inviabilize o uso pelo serviente. Se a um prédio falta uma boa estrada para o escoamento de sua produção, pode abrir um caminho pelo imóvel do outro, desde que se restrinja ao trânsito. A noção da socialidade, que é um dos princípios do Código Civil, governa o regime de servidões, e outro não é o fundamento do art. 1385: "restringir-se-á o exercício da servidão às necessidades do prédio dominante, evitando-se, quanto possível, agravar o encargo do prédio serviente".

Nessa linha de raciocínio, o legislador impõe peias ao exercício da posse pelo proprietário dominante, criando outras limitações. Assim, os $\S \S 1^{\circ}$ e $2^{\circ}$ daquele dispositivo vedam-lhe alterar a destinação da servidão ou ampliar seu grau de utilização. Logo, a servidão de eletroduto não permite ao proprietário dominante plantar a faixa por onde ela se estende. Autorizada passagem para o gado ir à fonte, não poderá o proprietário dominante apascentá-lo no terreno serviente. Um e outro comportamento constituem exemplos de alteração na finalidade do ônus real, vedação constante no primeiro parágrafo, graças ao qual "constituída para certo fim, a servidão não se pode ampliar a outro”.

Regra interessante encontra-se no segundo parágrafo. Cediço que o objeto da servidão não pode ser alterado ou ampliado, embora sempre implique o incremento da utilidade do prédio dominante, decorre ser possível ao proprietário deste praticar atos cuja amplitude seja inferior à amplitude da servidão. Logo, se alguém pode passar de caminhão por uma servidão, poderá também transitar a pé. Caminhar retrata um ônus menor que transitar com veículos. Mas o inverso não é admitido: constituída para a passagem de pedestres, a servidão não poderá ser empregada para o trânsito de veículos. Esse entendimento decorre da noção segundo a qual o proprietário serviente não é obrigado a tolerar mais do que autorizou. Por isso que o segundo parágrafo daquele dispositivo, referindo-se particularmente ao trânsito, dispõe que "nas servidões de trânsito, a de maior inclui a de menor ônus, e a menor exclui a mais onerosa".

Outro ponto a ser analisado repousa na conservação das servidões. Deixadas ao léu, tornam-se imprestáveis e por isso demandam a intervenção do titular. Este tem o direito de promover-lhes a conservação, mantendo-as em estado de viabilidade econômica. Pode, por isso, adentrar ao prédio serviente, mas seu ingresso deve estar limitado ao indispensável para os procedimentos de conservação. A 
esse direito a doutrina denomina servidão acessória, ou adminicula servitutis. A servidão de aqueduto, por exemplo, demanda inspeção regular, uma vez que entulhos podem impedir o fluxo de água. Nas servidões de trânsito de veículos, periódicas devem ser as inspeções e freqüentes as medidas de conservação, máxime em se tratando de via não pavimentada e achando-se na época das chuvas.

Daí o direito do titular dominante, previsto no art. 1380: "o dono de uma servidão pode fazer todas as obras necessárias à sua conservação e uso, e, se a servidão pertencer a mais de um prédio, serão as despesas rateadas entre os respectivos donos”. De ressaltar, como já apontado, que o emprego da expressão "dono", para referir ao proprietário do prédio dominante, não é apropriada, tendo melhor cabida a fórmula "titular da servidão". Mas, se o titular da servidão tem o direito de conserva-la, é natural que as despesas daí decorrentes lhe sejam carreados, a menos que o contrato disponha em sentido contrário, como transparece da leitura do art. 1381.

Embora não se trate de fenômeno comum, é possível que a conservação da servidão seja atribuída ao dono do prédio serviente, de conformidade com o disposto no dispositivo acima referido. Se isso ocorrer, o proprietário serviente terá assumido obrigação de fazer, vale dizer, promover a conservação, o que decerto lhe demandará despesas. Caso ele, futuramente, se convença da inviabilidade econômica de seu imóvel, de modo a que se desinteresse por ele, poderá exonerar-se à obrigação entregando o prédio, total ou parcialmente, ao titular da servidão, segundo oriente do art. 1382, residindo aqui a única alteração que o Código de 2002 introduziu nas servidões. $\mathrm{O}$ direito de abandono é potestativo e, segundo Wasshington B. Monteiro (2003), pode ser exercido mesmo contra a vontade do dono do prédio dominante. Esclareça-se que a faculdade de abandono não tem por objeto a servidão, mas o próprio imóvel serviente, o que importa transmissão da propriedade ao dono do prédio dominante. Se este não o quiser aceitar, então deverá assumir o encargo de conservar a servidão (art. 1382, parágrafo único).

A criação de uma servidão, segundo o espírito seguido pelo legislador, deve restringir o mínimo possível o uso do prédio serviente. $\mathrm{O}$ titular deste não perde nem a posse nem a propriedade da área gravada, embora seu grau de uso e gozo sejam diminuídos. Por isso, poderá exercer atos sobre a servidão, contanto que não cause uma redução de sua utilidade. Seguindo essa idéia, calcada no já mencionado 
equilíbrio entre necessidade/sacrifício, autoriza a lei a remoção da servidão de um lugar para outro, dentro do prédio serviente. Tal poderá ocorrer em duas hipóteses: primeiro, por ato do dono do prédio serviente, desde que o faça a sua custa e não provoque diminuição da utilidade; segundo, pelo proprietário do dominante, desde que demonstre o incremento econômico a ser propiciado pela mudança e a ausência de agravamento do encargo. A iniciativa pode partir do titular do prédio dominante, mas a mudança do local da servidão estará condicionada ao "considerável incremento da utilidade", segundo a terminologia do art. 1384. Trata-se de um conceito jurídico indeterminado, cuja apuração deve ser feita pelo juiz.

Um exemplo ajudará no entendimento do problema. Constituída uma servidão de trânsito num imóvel pastoril, o proprietário deste, que agora quer plantar cafeeiros, pode removê-la para outra região do imóvel. Isso porque o caminho pode ser realizado no pasto, mas não na cultura cafeeira. Se a alteração do itinerário não causar um aumento substancial do percurso e for efetuada às expensas do serviente, não pode o dominante opor-se a ela.

Ainda uma observação se impõe quanto ao exercício da servidão. $\mathrm{O} \S 3^{\circ}$ do art. 1385 faculta ao titular da servidão ampliá-la sempre que aumentarem as necessidades do seu prédio. Com efeito, "se as necessidades da cultura, ou da indústria, do prédio dominante impuserem à servidão maior largueza, o dono do serviente é obrigado a sofrê-la, mas tem direito a ser indenizado pelo excesso". A expressão "maior largueza", que é também um conceito jurídico indeterminado, deve ser entendida como ampliação do ônus, agravamento da restrição no serviente. Enquadram-se aqui o aumento da captação de água em virtude da expansão da cultura irrigável do dominante e a substituição de cultura de café por sojicultura, a exigir a passagem de colheitadeiras pela servidão de trânsito.

A ampliação da servidão, nos moldes desse dispositivo, não depende da concordância do dono do prédio serviente. É-lhe obrigatória e seu fundamento repousa nos arts. 182 e 184 do Texto Constitucional, que prevêem a funcionalização social e econômica dos imóveis urbanos e rurais. $\mathrm{O}$ aumento da produtividade (cultura e indústria) é um dos pilares em que se assenta o princípio. Sem embargo, terá o dono serviente direito a indenização a ser convencionada entre as partes. Não existindo acordo, será ela arbitrada judicialmente. 


\section{CONCLUSÃO}

A análise ora empreendida sobre as servidões no novo Código Civil demonstra a quase nenhuma ocorrência de alterações em relação à literalidade anterior.Todavia, uma abordagem promovida a partir dos princípios que informam a nova ordem mostra que o instituto não mais pode ser compreendido segundo uma visão individualista $e$ egocêntrica, tal como se fazia na ordem anterior.

Isso demonstra a importância crescente dos princípios na exegese de um instituto civil. Compreender o fenômeno jurídico a partir de sua principiologia é tarefa que se impõe ao cientista do Direito, especialmente porque é em função dela que se fundamenta o Estado Brasileiro, onde sobressai o primado da dignidade da pessoa humana.

Os direitos reais limitados postulam esse tipo de abordagem, na medida em que constituem um desdobramento de um valor que concorre ativamente para a consecução dos objetivos do Estado Brasileiro, vale dizer o direito de propriedade.

\section{REFERÊNCIAS}

ARONNE, R. J. Por uma nova hermenêutica dos direitos reais limitados. Rio de Janeiro: Renovar, 1999;

DANTAS, F. C. (San Tiago). Programa de Direito Civil. Direito das Coisas. 3. ed. Rio de Janeiro: Rio, 1984.

MONTEIRO, W. B. Curso de Direito Civil. 37. ed. atual. por Carlos Roberto Dabus Maluf. São Paulo: Saraiva, 2003.

RIZZARDO, A. Das Servidões. Rio de Janeiro: AIDE, 1984.

RUGGIERO, R. de. Instituições de Direito Civil. Campinas: Bookseller, 1999.

VAMPRÉ, S. Manual de Direito Civil Brasileiro. v. II. Rio de Janeiro: F. Briguiet, 1920.

VENOSA, S. S. Direito Civil. v. 5. 3. ed. São Paulo: Atlas, 2003. 